\title{
Depigmented phenotypes inside a Salamandrina perspicillata population of the Campagna Romana (Latium, Italy)
}

\author{
Pierangelo Crucitti ${ }^{1}$, Stefano Doglio ${ }^{1}$, Luca Tringali ${ }^{1}$
}

\begin{abstract}
The authors report the finding of eight individuals of Salamandrina perspicillata (Savi, 1821) with aberrant body colour discovered within a large population of the species in the Natural Reserve "Macchia di Gattaceca and Macchia del Barco" (Campagna Romana, Latium).
\end{abstract}

Key words: Salamandrina, aberrant colouration, Central Italy.

Riassunto - Gli autori segnalano il rinvenimento di otto individui di Salamandrina perspicillata (Savi, 1821) caratterizzati da livrea anomala rinvenuti all'interno di una numerosa popolazione della specie nella Riserva Naturale "Macchia di Gattaceca e Macchia del Barco" (Campagna Romana, Lazio). trale.

Parole chiave: Salamandrina, colorazione anomala, Italia Cen-

\section{INTRODUCTION}

The existence of individuals with an aberrant colouration in the Urodela of the genus Salamandrina has long been known. Individuals of Salamandrina perspicillata (Savi, 1821) have been recorded with a full red back (G. Martorelli, in Camerano, 1885: one individual from the Lucca Province), partially albinos (Ramorino, 1863: one individual probably originating from Liguria; Lanza, 1946: one adult from Mount Ceceri near Fiesole, Florence), and fully albino individuals of Salamandrina terdigitata (Lacépède, 1788) (personal communication by S. Tripepi to Angelini: adult from the Pollino Mountains) (Lanza et al., 2006, Angelini et al., 2007). An unusual case is represented by an adult $S$. perspicillata from Percile (Rome) whose back shows both melanistic areas and yellow spots (Lanza \& Canestrelli, 2002; cited as $S$. terdigitata). The proportion between the total size of a population or the sample number, and the number of in-

\footnotetext{
${ }^{1}$ Società Romana di Scienze Naturali, Via Fratelli Maristi 43, 00137 Roma, Italia.

* Corresponding author: info@srsn.it

(C) 2016 Pierangelo Crucitti, Stefano Doglio, Luca Tringali
}

Received: 30 October 2015

Accepted for publication: 18 April 2016 dividuals showing an anomalous pattern, may represent a useful reference parameter, especially when it allows for comparisons with the results of similar researches conducted either on the same species (from the same site but in different time; or from a different site altogether) or different amphibian species. Unfortunately, quantitative researches describing anomalies inside a population are rare, and among Urodela one of the very few exceptions is the paper by Drake \& O'Donnell (2014) on the North American salamander Plethodon serratus (Grobman, 1944). Unsurprisingly and despite a recent surge of papers on the biology of the genus Salamandrina (Doria et al., 2015), up to now there is a complete lack of research in this field of study on this Italian endemism. The purpose of this paper is thus to provide such an assessment, using data collected during a now completed field monitoring and census of a sizeable population of $S$. perspicillata in the Roman Campagna (Crucitti et al., 2013), north east from Rome city area (Tringali et al., 2015). Finally the role played by the factors allowing the persistence of this polymorphism, relatively common in amphibians (Rivera et al., 2001), is discussed.

\section{MATERIALS AND METHODS}

\section{Study area}

The research site is the Fosso del Barco (Barco Stream; Monterotondo, Rome), altitude 70-100 m asl, a sub tributary of the River Tiber, located inside the "Macchia del Barco", a relic forest protected by the Natural Reserve "Macchia di Gattaceca and Macchia del Barco" (1162 ha; established by the LR 29 - 06/10/97; managed by the Public Agency Città Metropolitana di Roma Capitale Protected Areas Service) (Figs 1 and 2). Fosso del Barco is a semi-permanent stream, about $1050 \mathrm{~m}$ long and on average $2.3 \mathrm{~m}$ wide (min-max $0.9-12 \mathrm{~m}$ ), characterized by rapids, small waterfalls and moderately deep gullies. The stream bed is often obstructed by fallen trees. Fosso del Barco is sheltered by a dense deciduous oak wood with Quercus cerris as the dominant tree, the shrub level is largely invaded by Ruscus aculeatus. Aquatic fauna includes Rana italica, Bufo bufo, Lissotriton vulgaris and Natrix natrix, Trichoptera and Odonata larvae. Rattus rattus is common on along the stream banks (a potential predator 
of Urodela; Velo-Antòn \& Cordero-Rivera, 2011), while Apodemus cf. flavicollis is very common, around rocks and logs, sometimes syntopic with $S$. perspicillata (December 2012). The highly invasive and dangerous alien Louisiana crayfish (Procambarus clarkii) was found twice (1 adult, May 2014; 1 sub adult, November 2014).

\section{Methods}

This research has been conducted within the framework of the Memorandum of understanding 28/01/2004 between the Società Romana di Scienze Naturali and the Public Agency Città Metropolitana di Roma Capitale Protected Areas Service. The research has been authorised

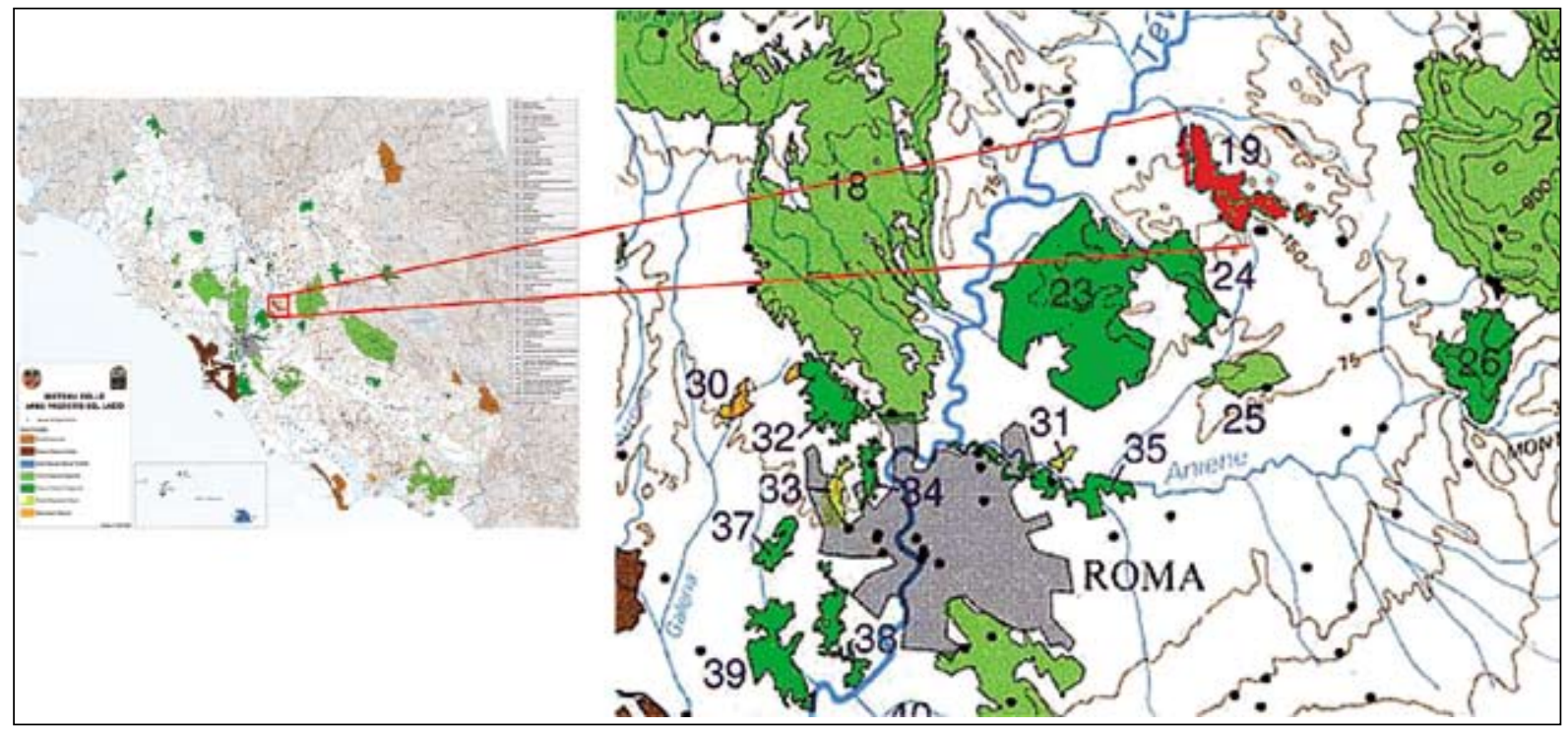

Fig. 1 - Location of the Natural Reserve "Macchia di Gattaceca e Macchia del Barco" in the Latium' protected areas system.

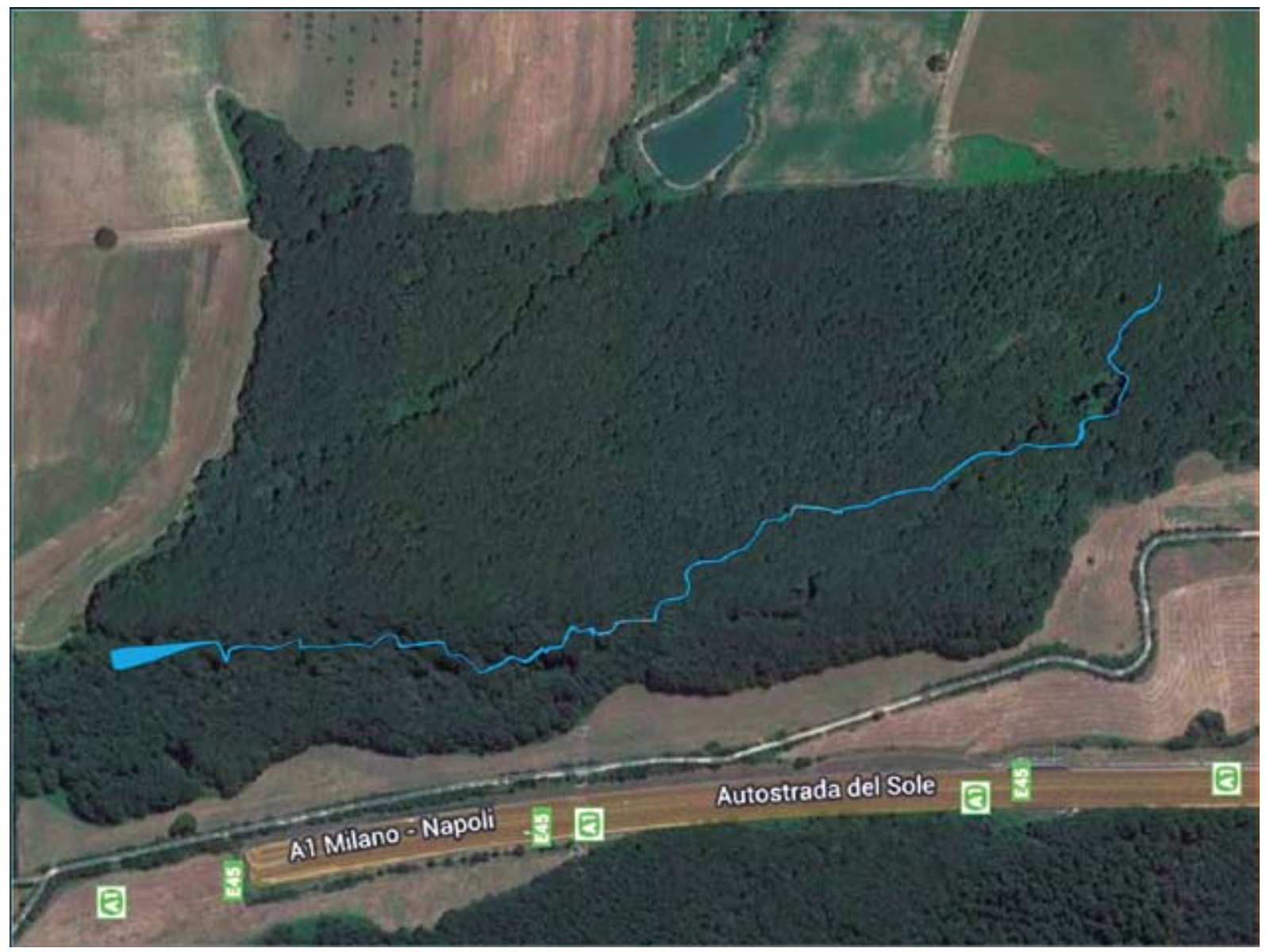

Fig. 2 - Fosso del Barco course inside Macchia del Barco. 
by the Italian Ministry of the Environment (protocol $\mathrm{n}$. 0015377 PNM of the 25/07/2014) according to the DPR 357/97 allowing the SRSN study group on Salamandrina to capture and handle $S$. perspicillata. Monitoring has been conducted from October 2012 to May 2015 for a total of 122 field surveys, 51 in daylight and 71 during the night.

The research protocol was to count and collect the adults and sub adults both in the forest and in the stream, as well as counting the larvae and eggs found under water. All the salamanders, including depigmented ones, have been marked by taking pictures of their ventral pattern for individual recognition (Tringali et al., 2015); all the pictures have been analysed by the Wild-ID 1.0 software (Bolger et al., 2011). Every captured individual was weighed. On the depigmented salamanders snout-vent length (SVL) and total length (TL) were also measured. At the end of each monitoring session, every captured salamander was released in the same spot where it had been previously collected.

\section{RESULTS}

The data of the eight individuals showing anomalous colours, and belonging to our monitored sample (2541 different individuals, i.e. excluding recaptured salamanders) and listed following the collection date are presented in Tab. 1. Seven individuals $(01,02,03,04,05,06$ and 08$)$ show a substantial depigmentation of the back that shows a fairly uniform yellowish colour and a complete lack of any black or dark shades. The belly appears paler than usual in the background colour and even more noticeably in the spotting. Individual 07 shows depigmentation of the back although less striking, as in this case there are also darker spots, while the belly looks more similar to the standard pattern of this species (Figs 3 and 4). Interestingly our research of $S$. perspicillata shows a ratio of the depigmented specimens compared to the general population they belong that's remarkably similar to the one recently observed and described in North America on the salamander Plethodon serratus by Drake \& O'Donnell (2014) (Tab. 2). The eight salamanders were found along the entire stream bed. Seven were found in activity, with air temperature ranging from 7.5 to $25.5^{\circ} \mathrm{C}$. Five were found on land moving around the leaf litter during a night visit, with temperatures ranging from 9.2 to $19.2^{\circ} \mathrm{C}$ and humidity between 56 and $96 \%$. Two individuals were recorded in water during daytime monitoring, with water temperature ranging from 11.5 to $13.0^{\circ} \mathrm{C}$.

\section{DISCUSSION}

Due to the lack of experimental validation derived from a fine-tuned morphological analysis (histological and ultrastructural) and especially on the degree of involvement of the eye (Capanna \& Foresti, 1974), we refrain from a precise diagnosis about the nature of the anomaly, and we adopt for the studied individuals the more generic term "depigmented" (or hypopigmented) with reference to a generic loss of cutaneous colouring. In a list of chromatic aberrations with a genetic base in amphibians, Lanza et al. (2006) mention albinism, melanism, piebaldism or partial albinism, axantism and leucism. A review of these anomalies in the European amphibians (Rivera et al., 2001) describes the categories of albinism (with its

Tab. 1 - GPS coordinates (North, East) and morphometrics. Nr: collection number of the individuals from 01 to 08 . Data: date of the observation (day. month. year). *Individual found in water while laying eggs (e.g. a female); **individual found in water (e.g. presumably a female) $* * *$ individual identified as a female by Antonio Romano (in litteris, 2015). TL (total length) and BL (body length): mm, weight: g.

\begin{tabular}{|c|c|c|c|c|c|c|c|c|}
\hline $\begin{array}{l}\text { Nr. } \\
\text { Date }\end{array}$ & $\begin{array}{l}01 \\
21 . I I .2013\end{array}$ & $\begin{array}{l}02 \\
7 . X I .2013\end{array}$ & $\begin{array}{l}03 \\
24 . X I .2013\end{array}$ & $\begin{array}{l}04 * \\
\text { 14.III.2014 }\end{array}$ & $\begin{array}{l}\text { 05** } \\
\text { 23.III.2014 }\end{array}$ & $\begin{array}{l}06 * * * \\
18 . I V .2014\end{array}$ & $\begin{array}{l}07 \\
20 . I V .2014\end{array}$ & $\begin{array}{l}08 \\
18 . X .2014\end{array}$ \\
\hline $\mathbf{N}$ & $42^{\circ} 04.408$ & $42^{\circ} 04.335$ & $42^{\circ} 04.402$ & $42^{\circ} 04.451$ & $42^{\circ} 04.136$ & $42^{\circ} 04.283$ & $42^{\circ} 04.402$ & $42^{\circ} 04.356$ \\
\hline $\mathbf{E}$ & $12^{\circ} 38.402$ & $12^{\circ} 38.413$ & $12^{\circ} 38.410$ & $12^{\circ} 38.401$ & $12^{\circ} 38.552$ & $12^{\circ} 38.446$ & $12^{\circ} 38.410$ & $12^{\circ} 38.402$ \\
\hline TL & 63 & 61 & 61 & 83 & 70 & 67 & 71 & 70 \\
\hline BL & 27 & 27 & 27 & 33 & 31 & 28 & 30 & 27 \\
\hline Weight & 0.47 & 0.52 & 0.50 & 1.18 & 1.04 & 0.59 & 0.63 & 0.55 \\
\hline
\end{tabular}

Tab. 2 - Comparison between the sample size (Npop) and the number of depigmented individuals (Ndep) in populations of two species of Urodela.

\begin{tabular}{|l|c|c|c|l|}
\hline Species & Npop & Ndep & Npop/Ndep \% & Source \\
\hline Plethodon serratus & 1876 & 6 & 0.32 & Drake \& O'Donnell, 2014 \\
\hline Salamandrina perspicillata & 2541 & 8 & 0.31 & This paper \\
\hline
\end{tabular}




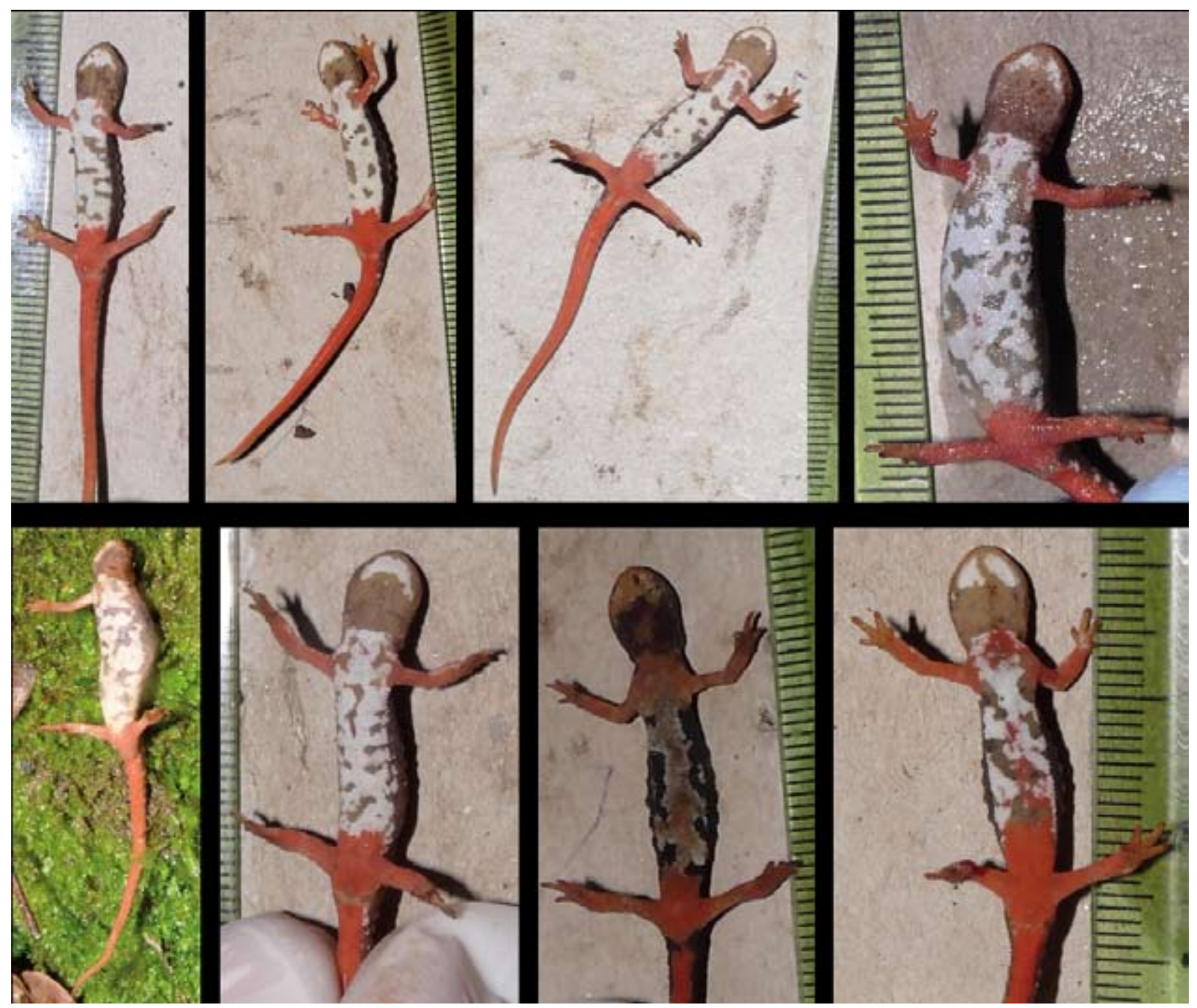

Fig. 3 - Individuals 01-08: dorsal view.

variants), leucism (with its variants), axantism, aniridism, melanism, erythrism, flavism (or xanthism). Based on this classification, our individuals from 01 to 06 and 08 could belong to the anomaly called "hipopigmentación" by the above authors, while the individual 07 could be placed into the "animales hipomelánicos" category (Rivera et $a l ., 2001)$. The hypopigmented pattern allows a comparison with the semi albino mutants category or "yellows" sensu Capanna \& Foresti (1974) and, according to these authors, the xantophores and chromatophores ("iridociti" in the paper) pattern is normal but the melanophores are either absent or lacking any colour.

Up to 2001, when the genus Salamandrina was still described as monotypic, there was only one paper out of a list of 78, mentioning partial albinism in a bibliography on the state of the art of anatomy and physiology of $S$. terdigitata s.l. (Vanni \& Zuffi, 2001). More generally, the bibliography on semialbinism and other colour anomalies in the amphibians could be reasonably divided into three different categories of papers. The first paper's group involves collecting the "historical" observations mentioned in the introduction: Lanza \& Canestrelli (2002), Radi
(2008) (the latter on the presence of an adult S. perspicillata showing a significant decolouration in the province of Grosseto), and Fiorenza (2012).

A second papers group deals with the difficult issue of semialbinism from an experimental point of view by morphological and ultrastructural observations, studying the issue also on the phenotype of the $\mathrm{F}_{2}$ hybrids: Capanna (1967, 1969, 1973), Capanna \& Foresti (1974). Specifically Capanna (1969) while discussing the data available at that time, suggested that partial/semi albinism is not a rare condition in amphibians; he also suggested that the disappearance of the cryptic pattern would expose the partially albino mutants to a higher rate of predation. This interpretation has been reclaimed sic et simpliciter by Crucitti \& Gentili (1987).

The third papers group (Drake \& O'Donnell, 2014; Jablonski et al., 2014) would provide a substantial set of data about the variable frequency, sometimes not at all negligible, of phenotypes featuring anomalous colour patterns both in Urodela as in Anura. Jablonski et al. (2014) first mention that "natural selection usually eliminates any aberrations that occur", but also notes that 


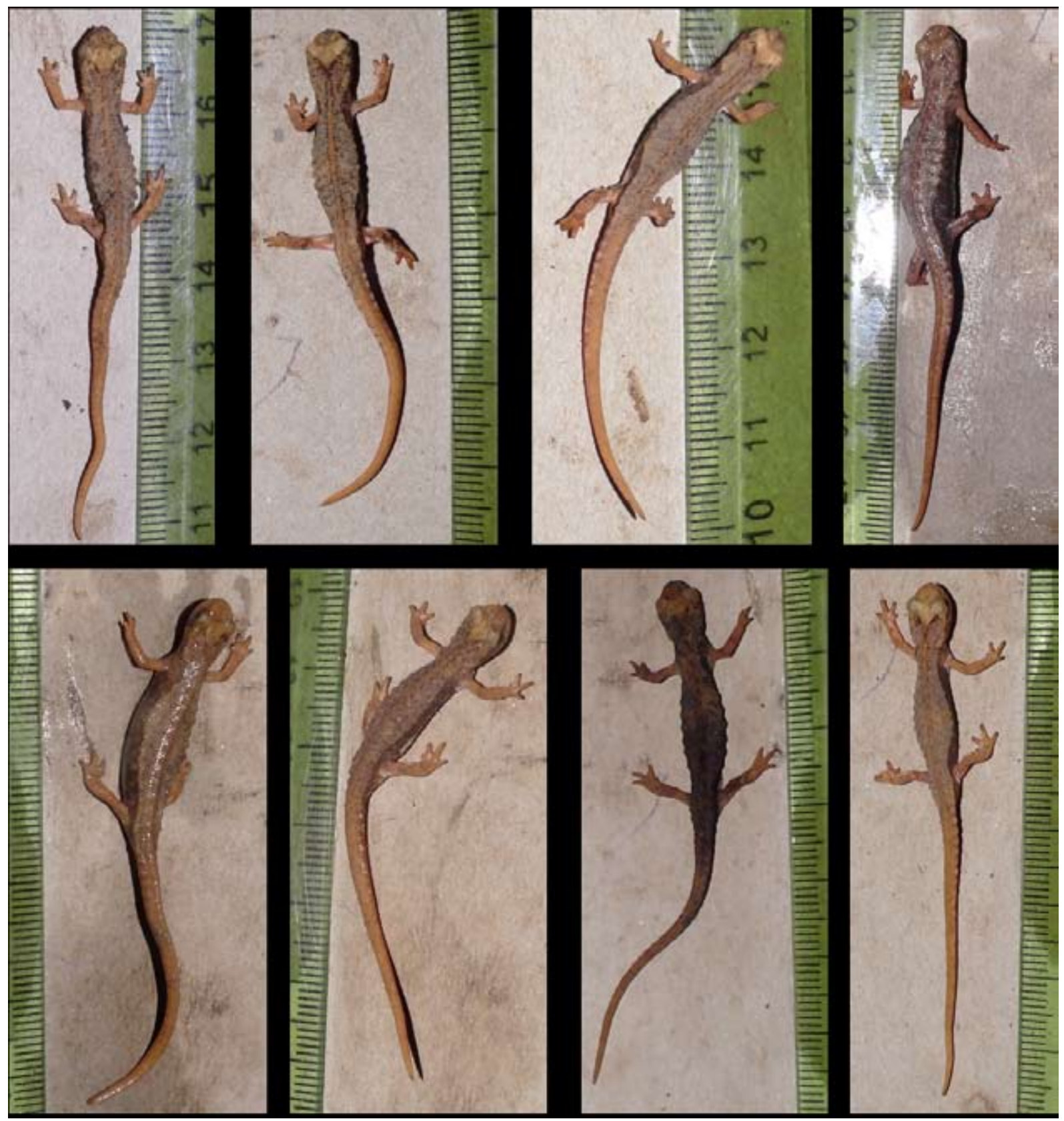

Fig. 4 - Individuals 01-08: ventral view.

populations with sometimes high percentages of anomalous coloured individuals of several amphibians or reptile species do survive and breed. The existence, in our sample, of adult females of $S$. perspicillata observed in activity in water seems to corroborate the hypotheses of a normal reproductive behaviour in the depigmented salamanders we found. Moreover, Jablonski et al. (2014), while noting a very low frequency of individuals showing axantism in the Bufotes viridis complex, verify, in the Anuran bibliography they analyse, frequency of axantism varying from 0.1 to $8.5 \%$. The remarkable variability of this phenomenon recommends to quantitatively assess, whenever feasible, the frequency of anomalous colour patterns, because such studies would allow the emergence of ecological and evolutionary explanatory hypothesis.
Fitzpatrick et al. (2009) describe the case of the Blue Jay (Cyanocitta cristata) a bird preying also on salamanders. This species has a "search image" that is more frequently selected toward the commonest phenotype of polymorphic terrestrial salamander species, such as Plethodon serratus, P. ventralis (Highton, 1997) and Batrachoseps attenuatus (Eschscholtz, 1833) leading to a progressive frequency increase of the rare, anomalous coloured phenotypes. Observations suggest that, at least in some ecological contexts, aberrant phenotypes are favoured by the so called apostatic selection as predators usually target individuals with a more typical pattern (Drake \& O'Donnell, 2014). However, we cannot currently explain the significance of the existence and survival of the depigmented Salamandrina perspicillata in our study site, both 
for the relatively small percentage of individuals showing an anomalous colouring and the complete lack of quantitative, comparable studies. Regular, long term or periodic monitoring of different populations and species, followed by a comparison of the collected data, could provide a useful methodological strategy for a better understanding of this problem.

\section{Acknowledgments}

We thank Antonella Antonelli for the help in understanding some of the papers, Antonio Romano for his always sound advice and Amanda Borrows for reviewing the English version of this paper. We also thank the numerous members of the Società Romana di Scienze Naturali who have contributed to this paper by collaborating for several years in field monitoring.

\section{REFERENCES}

Angelini C., Vanni S. \& Vignoli L., 2007 - Salamandrina terdigitata (Bonnaterre, 1789) - Salamandrina perspicillata (Savi, 1821): 228-237. In: Fauna d'Italia. 42. Amphibia. Lanza B., Andreone F., Bologna M.A., Corti C. \& Razzetti E. (eds.). Edizioni Calderini de Il Sole 24 Ore S.r.l., Bologna.

Bolger D.T., Vance B., Morrison T.A. \& Farid H., 2011 Wild-ID User Guide: Pattern Extraction and Matching Software for Computer-Assisted Photographic MarkRecapture Analysis. http://www.dartmouth.edu/ envs/ faculty/bolger.html

Camerano L., 1885 - Monografia degli Anfibi Urodeli italiani. Mem. R. Accad. Sc. Torino, (2) 36 (1884): 1-84; (2) 36 (1884): 405-486, tt. I-II; (2) 41: 403-481.

Capanna E., 1967 - Osservazioni sul semialbinismo negli Anfibi. Atti del $34^{\circ}$ Convegno dell'U.Z.I., Messina, 6 ottobre 1967. Bollettino di Zoologia, 34: 100.

Capanna E., 1969 - Albinismo parziale in una popolazione insulare di Discoglossus sardus Tschudi. Bollettino di Zoologia, 36: 135-141.

Capanna E., 1973 - Biological observations on the incomplete albinism of the Crested Newt (Triturus cristatus Laur.). Archives de Biologie, Bruxelles, 84: 377-415.

Capanna E. \& Foresti V., 1974 - Analisi dello sviluppo di un mutante semiabino di Triturus cristatus / Developmental analysis of a semialbino mutant of Triturus cristatus. Rivista di Biologia (bilingual edition in Italian and English), 67: 19-45.

Crucitti P., Amori G., Battisti C. \& Giardini M., 2013 Check-list degli Anfibi, Rettili, Uccelli e Mammiferi dell'area "arcipelago mentanese-cornicolano" (Campagna Romana, Lazio). Bollettino del Museo Civico di Storia NaturalediVerona,37, BotanicaZoologia:29-46.

Crucitti P. \& Gentili G., 1987 - Un fenotipo semialbino di Triturus cristatus karelinii (Strauch, 1870) (Amphibia). Atti della Società italiana di Scienze Naturali e del Museo Civico di Storia Naturale di Milano, 128 (1-2): 57-61.

Doria G., Poggi R., Salvidio S. \& Tavano M., 2015 - Atti $10^{\circ}$ Congresso Nazionale della Societas Herpetologica Italica. Genova, 15-18 ottobre 2014. Ianieri Edizioni, Pescara.
Drake D.L. \& O’Donnell K.M., 2014 - Sampling of Terrestrial Salamanders Reveals Previously Unreported Atypical Color Morphs in the Southern Red-backed Salamander Plethodon serratus. American Midland Naturalist, 171: 172-177.

Fitzpatrick B.M., Shook K. \& Izally R., 2009 - Frequency-dependent selection by wild birds promotes polymorphism in model salamanders. BMC Ecology, 9: 12-17.

Fiorenza T., 2012 - A case of possible axanthism in an alpine newt, Ichthyosaura alpestris alpestris (Laurenti, 1768) (Amphibia, Urodela). Bollettino del Museo di Storia Naturale di Venezia, 63: 115-120.

Jablonski D., Alena A., Vlček P. \& Jandzik D., 2014 - Axanthism in amphibians: A review and the first record in the widespread toad of the Bufotes viridis complex (Anura: Bufonidae). Belgian Journal of Zoology, 144: 93-101.

Lanza B., 1946 - Un caso di semialbinismo in Salamandrina terdigitata (Lacépède). Natura, Milano, 37 (1-2): 18-20.

Lanza B. \& Canestrelli D., 2002 - Atypische Färbung bei Salamandrina terdigitata (Lacépède, 1788) und $B u$ fo viridis viridis Laurenti, 1768. Salamandra, 38 (2): 105-108.

Lanza B., Nistri A. \& Vanni S., 2006 - Iconografia degli Anfibi d'Italia. / Iconography of Italian Amphibians. (Ministero dell'Ambiente e della Tutela del Territorio e del Mare - Direzione per la Protezione della Natura). Grandi \& Grandi Editori, Savignano sul Panaro (MO).

Radi G., 2008 - Quattro nuove stazioni di Salamandrina perspicillata (Savi, 1821) (Amphibia, Urodela) nella Provincia di Grosseto (Toscana). Atti Museo di Storia naturale della Maremma, 22: 123-128.

Ramorino G., 1863 - Appunti sulla storia naturale della Salamandrina perspicillata. Tipografia Sordo-Muti, Genova.

Rivera X., Arribas O. \& Martí F., 2001 - Revisión de anomalias pigmentarias en los Anfibios de la Peninsula Ibérica y de Europa. Butlleti de la Societat Catalana d'Herpetologia, 15: 59-75.

Tringali L., Bombarda F., Brocchieri D., Castelluccio P., Doglio S., Falcone G., Emiliani F., Marugàn S., Pernice S., Zanuccoli F. \& Crucitti P., 2015 - Il ciclo biologico di Salamandrina perspicillata della "Macchia del Barco" (Campagna Romana, Lazio). In: Atti 10 Congresso Nazionale della Societas Herpetologica Italica, (Genova, 15-18 ottobre 2014). Doria G., Poggi R., Salvidio S. \& Tavano M. Ianieri Edizioni, Pescara: 127-132.

Vanni S. \& Zuffi M.A.L., 2001 - Stato delle conoscenze anatomiche e fisiologiche in Salamandrina terdigitata (Lacépède, 1788) (Amphibia Caudata Salamandridae). In: Atti $3^{\circ}$ Congresso nazionale SHI (Pavia, 2000). Pianura, 13: 95-100.

Velo-Antòn, G. \& Cordero-Rivera A., 2011 - Predation by invasive mammals on an insular viviparous population of Salamandra salamandra. Herpetology Notes, 4: 299-301. 